\title{
Jules Joseph Dejerine: an outstanding neurologist and Charcot's enemy
}

\author{
Jules Joseph Dejerine: neurologista excepcional e inimigo de Charcot \\ Gustavo Koíti Kondo', Carla Caroline Schramm¹, Max Rainer Rosado Novaes', Hélio Afonso Ghizoni Teive1
}

\begin{abstract}
Jules Joseph Dejerine (1849-1917) became renowned for his many contributions to neurology, including his anatomical and anatomo-functional studies, particularly those in the field of language and the peripheral nervous system. A disciple of Vulpian and a rival of Charcot, Dejerine progressed rapidly in the academic world, reaching the peak of his career in 1911, when he was appointed to the chair of Nervous System Diseases at the Salpêtrière Hospital after defeating Pierre Marie (1853-1940), one of the most distinguished pupils of Jean-Martin Charcot (1825-1893).
\end{abstract}

Keywords: neurology; history; language; central nervous system; peripheral nervous system.

\section{RESUMO}

Jules Joseph Dejerine (1849-1917) destacou-se na neurologia com seus estudos anatômicos e anatomo-funcionais sobretudo na área da linguagem e sistema nervoso periférico. Discípulo de Vulpian e rival de Charcot, Dejerine ascendeu rapidamente na carreira acadêmica, com seu ápice em 1911 quando assumiu a cadeira de Doenças do Sistema Nervoso em La Salpêtrière, derrotando Pierre Marie (1853-1940), um dos mais notáveis pupilos de Jean-Martin Charcot (1825-1893).

Palavras-chave: neurologia; história; linguagem; sistema nervoso central; sistema nervoso periférico.

At the end of the nineteenth century, the death of Prof. Jean-Martin Charcot (1825-1893), the founder of clinical neurology (Figure 1), left vacant the very important chair of Nervous System Diseases at the Salpêtrière Hospital, in Paris, France, giving rise to much speculation about who would succeed him ${ }^{1,2}$. For a short period between 1893 and 1894, Édouard Brissaud (1852-1909), a disciple of Charcot, was appointed interim chair ${ }^{1,23}$. A year after Charcot's death, one of his disciples, Fulgence Raymond (1844-1910), was appointed to the chair in preference to the other candidates, Édouard Brissaud and Jules Joseph Dejerine (1849-1917), the latter standing out, not only because of his remarkable résumé, but also because he was one of Charcot's most important rivals ${ }^{1,23}$. Dejerine had to wait until 1911, after Raymond died in 1910, to be appointed to the chair over one of Charcot's most important pupils, Pierre Marie (1853-1940) ${ }^{1,2,3,4}$. In this article, we review the life of Jules Joseph Dejerine, his contributions to neurology and his rivalry with Charcot.

\section{JULES JOSEPH DEJERINE - A BIOGRAPHY}

Jules Joseph Dejerine (Figure 2) was born on August $3^{\text {rd }}, 1849$, in Geneva, Switzerland ${ }^{1,2,3,4,5,6}$. The son of French parents with a modest income, Dejerine was initially a notable student but became better known for his sporting abilities - boxing and swimming - than for his academic prowess ${ }^{1,2,3,4,5}$. His life changed when he traveled to Paris at the age of 22, armed only with a letter of introduction from Jean-Louis Prévost, a Swiss neurologist (1838-1927), to Félix Alfred Vulpian (1826-1887), one of

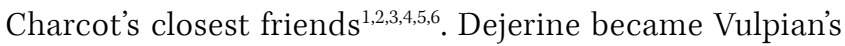
most important disciple, and his academic career progressed rapidly. ${ }^{1,2,5,6}$ In 1875, he was appointed as a consultant at the Pitié Hospital ${ }^{1,2,3,5,6}$. In 1879, he was appointed to the Bicêtre Hospital and became head of department and, in 1886, he was appointed associate professor ${ }^{1,2,3,5,6}$. In 1887, he started working at the Salpêtrière Hospital on Vulpian's recommendation and with Charcot's approval. In 1911, he was appointed to the chair of Nervous System Diseases, which had previously been held by Jean-Martin Charcot, following a public examination ${ }^{1,2,3,5,6}$. Dejerine was married to Augusta Marie Klumpke (1859-1927), who helped him with many clinical and anatomical-pathological studies ${ }^{1-6}$. He died in February 1917, at the age of 68, from uremia secondary to Bright's disease, a peculiar form of glomerulonephritis ${ }^{1,2,3,4,5,6}$.

\footnotetext{
'Universidade Federal do Paraná, Hospital de Clínicas, Departamento de Medicina Interna, Serviço de Neurologia, Curitiba PR, Brasil. 


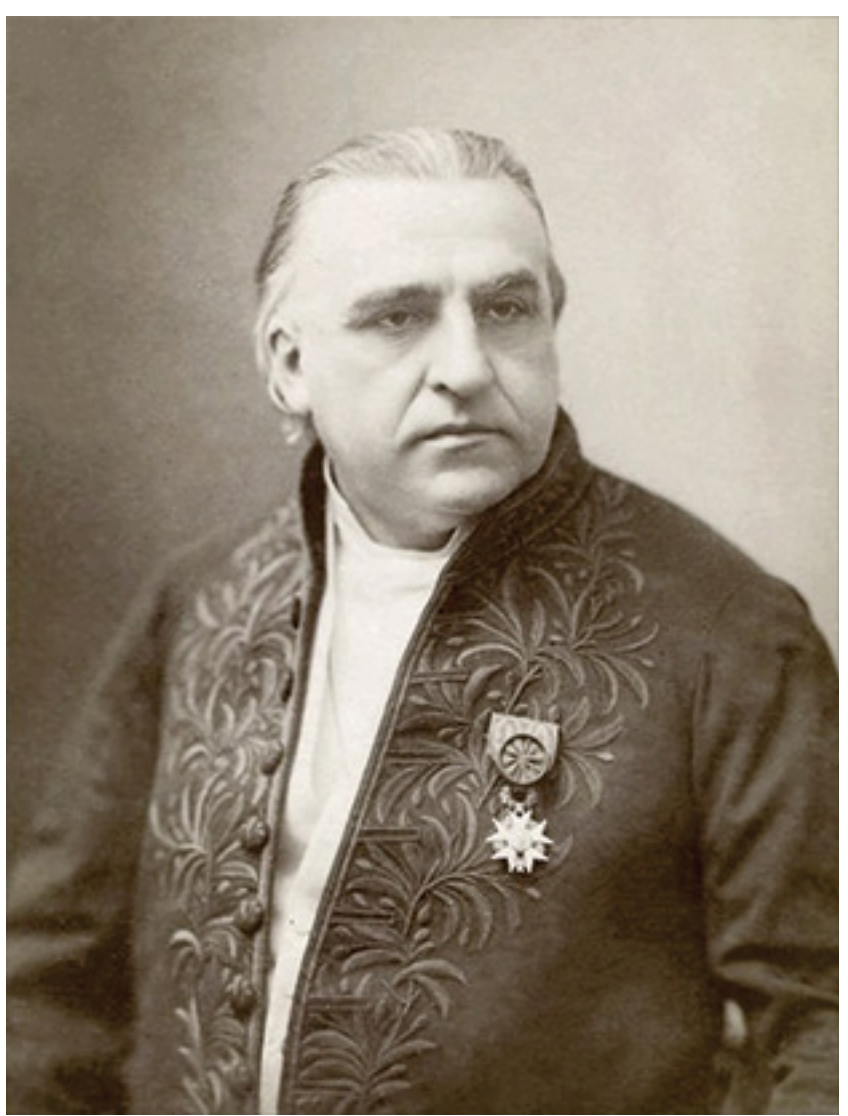

Figure 1. Jean-Martin Charcot (1825-1893).

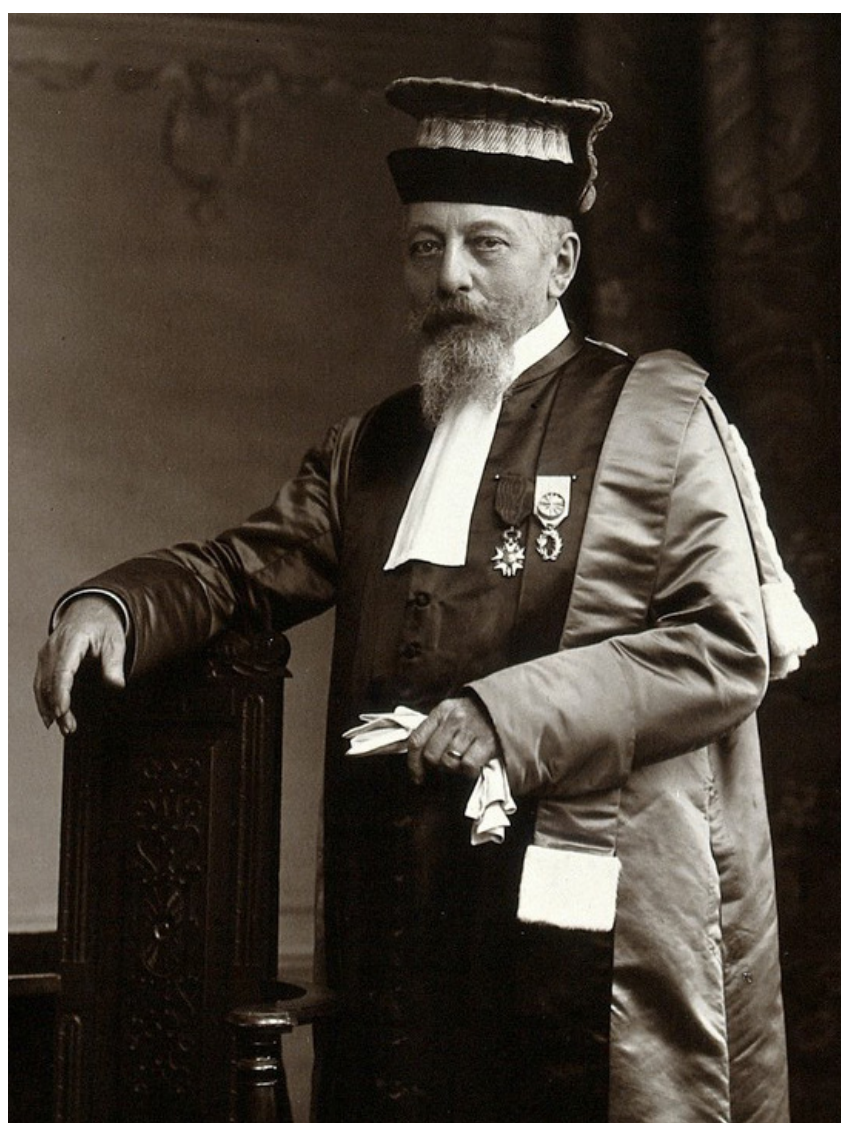

Figure 2. Jules Joseph Dejerine (1849-1917).

\section{DEJERINE'S CONTRIBUTIONS TO NEUROLOGY}

Jules Dejerine's contributions to neurology spanned more than 40 years and included anatomical and anatomo-functional studies $^{1,2,5,6}$. His first major contribution was a description of alexia, including alexia with and without agraphia, in 1892 1,25,6. Between 1895 and 1901, he published the book Anatomie des Centres Nerveux, his great anatomo-functional study, in which he described the trajectories of the projection fibers and association fibers that connect the nerve centers making up the neural circuits, highlighting the language circuit ${ }^{1,2,5,6}$. Another of his famous works was the book on semiology, Sémiologie des affections du système nerveux, which was published in $1914^{1,2,5,6}$. He made a significant contribution to the description of pathologies of the peripheral nervous system, most notably by defining radiculitis, characterizing inflammatory demyelinating polyradiculoneuropathy and meningoradiculitis and developing a three-part test to assess radicular pain that came to be known as Dejerine's $\operatorname{triad}^{1,2,5,6,7}$. His other important contributions to neurology include a description of a form of myopathy known as facioscapulohumeral muscular dystrophy (LandouzyDejerine disease), a hereditary peripheral neuropathy known as Dejerine-Sottas disease, a form of plexopathy (DejerineKlumpke plexopathy), olivopontocerebellar atrophy (DejerineThomas syndrome) and Dejerine-Roussy syndrome (thalamic syndrome) $)^{1,2,3,5,6,7.7}$.

\section{DEJERINE VERSUS CHARCOT}

Alfred Vulpian and Charcot were residents in the same institute in 1848, and became very close friends, later working together as heads of department at Salpêtrière Hospital in 1862, carrying out studies together (on, for example, multiple sclerosis) and coauthoring various papers ${ }^{1,2,4,8}$. Although they got on well with each other, their academic careers evolved differently. Vulpian progressed rapidly and was appointed professor, a member of the National Academy of Medicine, a member of the Academy of Sciences and, later, dean of the Paris Faculty of Medicine. Charcot's academic career, by contrast, progressed more slowly, and it was not until 1882 that it culminated in his appointment as chair of Diseases of the Nervous System ${ }^{1,4,8}$. After 1882, a certain rivalry between them became evident in their pupils - Pierre Marie, Charcot's most loyal disciple, and Dejerine ${ }^{1,2,9}$, who was renowned as Vulpian's most brilliant disciple and had never worked with Charcot's group at the Salpêtrière Hospital ${ }^{1,2,3,89}$. Although they respected each other, there was great rivalry between them and Charcot himself said that Dejerine had a stronger personality than his pupils, which became evident in the examination for the position of associate professor in $1886^{1,2,3,8,9}$. From that time on, Dejerine started to behave antagonistically toward Charcot and his disciples and became their scientific rival and enemy $y^{1,2,3,9}$. 
Dejerine, in addition to competing with Charcot for the academic position, also represented an intellectual force from outside Salpêtrière ${ }^{1,2,3,8,9}$. From Charcot's death in 1893, until 1910, Dejerine and Pierre Marie also became rivals, reflecting the indirect conflict between Vulpian and Charcot ${ }^{1,2,3,9}$. Both held opposing views on the location of language areas in the brain, a dispute that came to a head in 1908, when the Paris Aphasia Debate took place at the Paris Neurology Society ${ }^{1,2,3,10}$. While Dejerine was at the pinnacle of his career between 1911 and 1917, Pierre Marie had to wait until 1918, the year after Dejerine's death, to occupy the chair of his great, idolized master, Jean-Martin Charcot Ch, $2,3,4,5,6,9^{\text {. }}$

\section{CONCLUSION}

During the late $19^{\text {th }}$ and early $20^{\text {th }}$ centuries, Jules Dejerine was one of the great names of French and international neurology $y^{1,2,3,4}$. Achieving rapid academic progression, he published anatomical and anatomo-functional studies with an emphasis on language and the central and peripheral nervous systems for over 40 years ${ }^{1,2,3,6,7}$. A disciple of Vulpian and rival of Charcot, he reached the peak of his career between 1911 and 1917, when he was appointed over Pierre Marie to the chair of Nervous System Diseases at Salpêtrière Hospital11,2,3,4,5,6.

\section{References}

1. Goetz CG, Bonduelle M, Gelfand T. Charcot's death and legacy. In: Goetz CG, Bonduelle M, Gelfand T. Charcot: constructing neurology. New York:, Oxford University Press; 1995., p. 305-332.

2. Clarac F, Boller F. History of neurology in France. Handb Clin Neurol. 2010;95:629-56. https://doi.org/10.1016/S0072-9752(08)02140-4

3. Paciaroni M, Bogousslavsky J. Jules Joseph Dejerine versus Pierre Marie. In: Bogousslavsky J, editor. Following Charcot: a forgotten history of neurology and psychiatry. Basel: Karger; 2010. (Frontiers of neurology and neuroscience, Vol. 29)>. p. 162-9.

4. Tatu L, Bogousslavsky J. The impossible succession of Charcot: the quest for a suitable heir. Eur Neurol. 2011;65(4):193-7. https://doi.org/10.1159/000324333

5. Ellis H. Jules Joseph Dejerine: distinguished French neurologist. Br J Hosp Med (Lond). 2017 Feb;78(2):115.

6. Gauckler E. Le professeur J. Dejerine, 1849-1917. Paris: Masson; 1922.
7. Mathis S, Vallat J-M. Jules Dejerine and the peripheral nervous system. Neurology. 2017 Aug;89(6):611-5. https://doi.org/10.1212/WNL.0000000000004217

8. Bogousslavsky J, Walusinski O, Moulin T. Alfred Vulpian and JeanMartin Charcot in each other's shadow? From Castor and Pollux at la Salpêtrière to neurology forever. Eur Neurol. 2011;65(4):215-22. https://doi.org/10.1159/000325733

9. Walusinski O. Jules and Augusta Dejerine, Pierre Marie, Joseph Babinski, Georges Guillain and their students during World War I. Revue Neurol (Paris). 2017 Mar;173(2):114-24. https://doi.org/10.1016/j.neurol.2017.02.001

10. Lecours A, Chain F, Poncet M, Nespoulous JL, Joanette Y. Paris 1908: the hot summer of aphasiology or a season in the life of a chair. Brain Lang. 1992 Feb;42(2):105-52. https://doi.org/10.1016/0093-934X(92)90121-T 